\title{
The adoption of governance mechanisms in family businesses: an institutional lens
}

\author{
Maria Jose Parada \\ Department of Strategy and General Management, \\ ESADE Business School, Universitat Ramon Llull, Barcelona, Spain \\ Alberto Gimeno \\ ESADE Business School, Universitat Ramon Llull, Barcelona, Spain \\ Georges Samara \\ American University of Beirut, Lebanon, Beirut and IPAG Family Buisness Institute, \\ Institute of Preparation for Administration and Management (IPAG), Paris, \\ France, and \\ Willem Saris \\ Universitat Pompeu Fabra, Barcelona, Spain
}

\begin{abstract}
Purpose - Despite agreement on the importance of adopting governance structures for developing competitive advantage, we still know little about why or how governance mechanisms are adopted in the first place. We also acknowledge that family businesses with formal governance mechanisms in place still resort to informal means to make decisions, and we lack knowledge about why certain governance mechanisms are sometimes, but not always, effective and functional. Given these research gaps, and drawing on institutional theory, we aim to explore: How are governance structures adopted and developed in family firms? Once adopted, how do family businesses perceive these governance structures?

Design/methodology/approach - Using Mokken Scale Analysis, a method suitable to uncover patterns/ sequences of adoption/acquisition over time, we analyze a dataset of 1,488 Spanish family firms to explore if there is a specific pattern in the implementation of governance structures. We complement the analysis with descriptive data about perceived usefulness of such structures.

Findings - Our findings highlight two important issues. Family businesses follow a specific process implementing first business governance (board of directors, then executive committee), followed by family governance (family council then family constitution). We suggest they do so in response to institutional pressures, given the exposure they have to business practices, and their need to appear legitimate. Despite formal adoption of governance structures, family businesses do not necessarily consider them useful. We suggest that their perception about the usefulness of the implemented governance structures may lead to their ceremonial adoption, resulting in a gap between the implementation and functionality of such structures.

Research limitations/implications - Our article contributes to the family business literature by bringing novel insights about implementation of governance structures. We take a step back to explain why these governance mechanisms were adopted in the first place. Using institutional theory we enrich governance and family business literatures, by offering a lens that explains why family businesses follow a specific process in adopting governance structures. We also offer a plausible explanation as to why governance structures are
\end{abstract}

(C) Maria Jose Parada, Alberto Gimeno, Georges Samara and Willem Saris. Published by Emerald Publishing Limited. This article is published under the Creative Commons Attribution (CC BY 4.0) licence. Anyone may reproduce, distribute, translate and create derivative works of this article (for both commercial \& non-commercial purposes), subject to full attribution to the original publication and authors. The full terms of this licence may be seen at http://creativecommons.org/licences/by/4.0/ legalcode.

The authors are grateful for the support and constructive feedback of the Guest Editor and reviewers of the Special Issue given in the several rounds of reviews.

The adoption of governance mechanisms
Received 22 July 2019 Revised 20 September 2019

11 November 2019

10 December 2019

Accepted 14 December 2019 
ineffective in achieving their theorized role in the context of family businesses, based on the family's perception of the unusefulness of such structures, and the concept of ceremonial adoption.

Practical implications - There is no single recipe that can serve the multiple needs of different family businesses. This indicates that family businesses may need diverse levels of development and order when setting up their governance structures. Accordingly, this study constitutes an important point of demarcation for practitioners interested in examining the effectiveness of governance structures in family firms. We show that an important pre-requisite for examining the effectiveness of governance structures is to start by investigating whether these structures are actually being used or are only adopted ceremonially.

Originality/value - Our paper expands current knowledge on governance in family firms by taking a step back hinting at why are governance structures adopted in the first place. Focusing on how governance is implemented in terms of sequence is novel and relevant for researcher and practitioners to understand how this process unfolds. Our study uses institutional theory, which is a strong theory to support the results. Our paper also uses a novel method to study governance structures in family firms.

Keywords Family business, Governance, Institutional theory, Institutional pressures, Ceremonial adoption Paper type Research paper

\section{Introduction}

Scholars and practitioners agree that family business governance mechanisms differ from mainstream governance, due to the unique characteristics of family businesses, including their long-term vision, their desire to preserve wealth for future generations (Le Breton-Miller and Miller, 2006), and their pursuit of both family-centric and business-oriented goals (Aparicio et al., 2017; Samara and Paul, 2019). Extensive research also highlights the importance of such governance structures in developing competitive advantage and differentiation (e.g. Miller and Le Breton-Miller, 2005; Carney, 2005; Gedajlovic and Carney, 2010). Governance structures, if absent or only implemented on paper, can also destroy family business value (Goel et al., 2014).

Academics argue that family businesses need to establish efficient governance structures to deal with two overlapping systems: the family and the business (Lansberg, 1983; Neubauer and Lank, 1998). Business issues are related to the organization of administration (supervision, control, monitoring), and these issues are addressed with business governance mechanisms such as the organization of the top-management team (TMT) and the deployment of the board of directors (cf. Neubauer and Lank, 1998). Family issues require family governance mechanisms, for building cohesion, developing a shared vision and reducing conflicts between family members (Mustakallio et al., 2002). These family governance mechanisms essentially include family meetings, namely family councils (Gallo and Kenyon-Rouvinez, 2005), and written documents containing certain rules in the form of constitutions, among other mechanisms. Thus far, current literature has introduced four main governance mechanisms in family firms: family council, board of directors, executive committee and family constitution (Aronoff and Ward, 1996; Gersick et al., 1997; Ward, 1987). These mechanisms have been highlighted as essential for achieving long-term sustainability of the family business.

While most studies have mainly concentrated on the effectiveness of the board of directors (e.g. Zahra and Pearce, 1989; Corbetta and Salvato, 2004), there is little research as to how and why family firms adopt other business and governance mechanisms, such as the family council and the executive committee. Moreover, even though these governance mechanisms have been prescribed for family businesses and implemented by a large number of them (Melin and Nordqvist, 2007) to enhance business prosperity and corporate accountability (Keasey et al., 2005), for every story of a well-governed and successful family business, there are other stories of family businesses that have failed and eventually collapsed, even amongst those that adopted the four governance mechanisms (Samara and Arenas, 2017). There is evidence that family businesses that have adopted these governance mechanisms still resort to informal means to make decisions, such as making decisions at-the-dinner-table or through informal conversations between family members. This indicates that we still know little 
about why certain governance mechanisms are sometimes, but not always, effective and functional (Corbetta et al., 2002). Given these research gaps, our article aims to explore the following questions: How are governance structures adopted and developed in family firms? And, once adopted, how do family businesses perceive these governance structures?

To address these questions, we draw on institutional theory, more specifically on the concepts of institutional pressures (DiMaggio and Powell, 1983), legitimacy (Suchman, 1995b) and ceremonial adoption (Meyer and Rowan, 1977). Our theoretical approach allows us to discuss, first, the process through which family businesses adopt certain governance structures, and to explain, later, the plausible reasons behind the potential gap between the implementation and the functioning of governance structures. To explore the pattern through which governance structures in family businesses unfold, we use a sample of 1,488 Spanish family businesses and apply a Mokken Scale Analysis, an unexplored method in the family business field that particularly suits the purposes of this study.

Our findings highlight two important issues. First, family businesses follow a specific process to develop governance structures. To begin with, they implement business governance mechanisms, starting with the board of directors and followed by the executive committee. Then, they proceed to adopt family governance mechanisms by establishing a family council, followed by a family constitution. Given that they follow a specific pattern in adopting governance mechanisms, we suggest that family businesses do so in response to institutional pressures. Therefore, family firms may start with business governance, given the exposure they have to business practices, and their need to appear legitimate (Suchman, 1995b). Second, even though they adopt these governance mechanisms, family businesses do not necessarily consider them useful. Therefore, we suggest that their perception about the usefulness of the implemented governance structures may lead to their ceremonial adoption (Zucker, 1987), hence resulting in a gap between the implementation and functionality (effective performance) of such structures (Corbetta et al., 2002).

Our article contributes to the family business literature by bringing novel insights about the implementation of governance structures. While debates have revolved around governance and performance, we take a step back to explain why these governance mechanisms were adopted in the first place. In doing so, we offer a nuanced understanding about the interlinkages between governance and performance and offer another plausible explanation as to why governance structures are ineffective in achieving their theorized role in the context of family businesses. This article also contributes to the literature on governance by introducing an institutional lens (Di Maggio and Powel, 1983) to explain why family businesses follow a specific pattern when adopting governance structures. We maintain that institutional pressures lead to a specific process in adopting governance structures, starting with business governance mechanisms and ending with family governance mechanisms, hence hinting at coercive, mimetic and normative institutional pressures driving their adoption. We also show how the family's perception of the unusefulness of such structures can lead to ceremonial adoption (Suchman, 1995b), thereby echoing the growing calls to shed more light on the reasons behind the gap between the implementation and the functioning of governance structures (Corbetta et al., 2002; Poza, 2007).

This paper is structured as follows. First, we present a review of the literature on governance structures and proceed with our main theoretical framework: institutional theory. Then, we develop the methodology to explain the Mokken Scale Analysis and how it has been used in previous studies in similar fields (e.g. marketing). We continue with the results, and we finally discuss our conclusions, limitations, and avenues for future research.

\section{Literature review}

Governance structures in family businesses

Governance in family businesses can be viewed as the result of a set of decisions made by the dominant coalition to direct and control the behavior of the business and family members (cf., 
Carney, 2005; Steier et al., 2015; Daily et al., 2003). These governance mechanisms include developing adequate structures to satisfy family businesses main stakeholders (e.g. Freeman, 1984; Neubauer and Lank, 1998; Ward, 1991) and to be able to effectively manage the overlap between the family and business systems (Samara and Paul, 2019).

Family businesses need to find effective ways to deal with the increasing family and business complexity that accompanies business growth and family expansion. In the early stages, when the founder acts as both owner and manager (e.g. Perez-Gonzalez, 2006; Villalonga and Amit, 2006; Miller and Le-Breton-Miller, 2007), higher efficiency and better performance are expected. This efficiency is related to the personal qualities of the founder, who finds it difficult to share or delegate authority and responsibility to other actors, and his/ her view of their own creation (McClelland, 1962). However, when complexity increases, this efficiency may decline, and current and future managers need to cope with the problems associated with business growth and family transitions across generations (Barry, 1989). This is when governance mechanisms can have an effective role in establishing order and the professionalization of processes in a growing and complex family business. Implementing different governance structures has been argued, theoretically, to lead to enhanced performance (Gimeno et al., 2010).

The family business literature has traditionally emphasized two overlapping systems, the family and the business, as well as the need to manage the tensions and overlap between them (Lansberg, 1983). Governance structures play a critical role in this. On the one hand, family governance has been prescribed for dealing with family issues, it is particularly important for building cohesion, developing a shared vision, and reducing conflicts (Mustakallio et al., 2002). Family governance has been recommended in the form of family councils (Gallo and Kenyon-Rouvinez, 2005). Moreover, in the search for effective governance, and as part of the increasing institutionalization of family businesses (Melin and Nordqvist, 2007), researchers highlight that family complexity may erode both the family and the business, therefore family policies are recommended to prevent this erosion (Aronoff and Ward, 1996). In that sense, the family constitution, which is a set of rules for the family and the business, becomes an integral part of the governance structure of family businesses.

On the business side, governance has been prescribed for dealing with business issues that are related to the organization of administration (supervision, control, monitoring, etc.). These issues are addressed by the top-management team (TMT) through the executive committee and the board of directors (Gimeno, 2006; Lansberg, 1999; Neubauer and Lank, 1998; Schwartz and Barnes, 1991; Ward, 1991; Ward and Handy, 1988). The board of directors is considered to be the formal mechanism for monitoring, controlling and developing strategic decisions, and the executive committee is responsible for implementing the strategic decisions taken at the board level. Thus, the family council, the board of directors, the executive committee and the family constitution represent the mechanisms that constitute family businesses governance structures (Aronoff and Ward, 1996; Gersick et al., 1997; Ward, 1987). Recent research suggests that the existence of each one of these mechanisms reinforces the functionality of the others (Gimeno et al., 2010) and highlights the need to configure governance structures in order to cope with the specific stages of the family-business lifecycle (Nordqvist et al., 2014).

Despite diverse attempts to broaden the understanding and knowledge about governance in family businesses, reviews highlight that this topic remains highly under-explored (Gersick and Feliu, 2014; Goel and et al., 2014), highlighting the need for more empirical research, while expanding the research methods (Zahra and Sharma, 2004). Particularly, we do not know the sequential process through which family businesses adopt these mechanisms, or whether they perceive these governance mechanisms as useful.

This research gap reflects the need to understand the reasons why family businesses adopt various governance structures to manage the overlapping family and business spheres 
better. Institutional theory can be used as a lens to help discuss, theoretically, how family businesses implement corporate governance structures.

\section{Institutional pressures, conformity and governance structures in family firms}

Social forces are said to greatly influence organizational action and decision-making (Granovetter, 1985). Organizations need and desire to fit in with their institutional environment and, in their search for legitimacy, they accept prescriptions based on institutional norms and rules (DiMaggio and Powell, 1983; Tolbert and Zucker, 1983). DiMaggio and Powell (1983) suggest that there are three institutional mechanisms that drive organizations towards conformity and homogenization in their aim to achieve legitimacy. These are mimetic, coercive, and normative pressures. Mimetic processes refer to the situation where organizations imitate or model themselves upon other organizations, whereas coercive processes result from formal and informal pressures exerted by (1) other organizations upon which organizations are dependent and (2) cultural expectations in society (DiMaggio and Powell, 1983). Finally, normative pressure refers to the process of professionalization, or the collective struggle to define the conditions and methods of a profession or form of organization.

Family businesses are also subject to institutional pressures as they are becoming an organizational field (Sharma, et al., 2014). A general discourse around the specific characteristics of this type of organizations has been created (Melin and Nordqvist, 2007), due to the increasing group of researchers, consultants, practitioners and professional associations (e.g. the Family Firm Institute, Family Business Network) and vast literature (books, journals, and magazines) that has emerged. Therefore, family businesses are becoming more exposed to institutional pressures from diverse institutions with regards to the adoption of governance structures and organizational practices. For instance, we observe that family firms tend to change their values over time, partly due to the interaction with professional associations that recommend and prescribe specific practices (cf. Parada et al., 2010).

Family businesses are exposed to macro-level forces stemming from the state as a supra institution (Scott, 2008) dictating laws, regulations, and codes of good governance (e.g. the Cadbury Report) for accountability and professionalization. Therefore, family businesses may feel the pressure to adopt a board of directors to conform to what is required by law. At an inter-organizational level, family businesses are exposed to consultants who advise them and professional associations (DiMaggio, 1988) who prescribe the best practices and specific values that are in line with what a family business should be (Parada et al., 2010). Family businesses are also exposed to specific logics derived from the family institution and the business institution (Gersick, et al., 1997; Lansberg, 1983; Samara and Paul, 2019) at an organizational level.

Therefore, family businesses adopt widely prescribed governance structures and practices (e.g. Melin and Nordqvist, 2007; Nordqvist and Melin, 2002; Parada et al., 2010) in their quest to appear legitimate. On the one hand, these organizations may adopt business governance structures to support decision-making, but also to look like publicly quoted businesses, to dilute stigma in the eyes of the critics who claim that family businesses are poorly professionalized (e.g. Chandler, 1962). On the other hand, the family business field prescribes specific family governance mechanisms to cope with family complexity (Gersick and Feliu, 2014), sometimes leading to mimetic adoption of such structures.

Likewise, family and business institutions operate using divergent logics, and their timings are also different. Family and business employ different time measurements. Literature suggests that it is difficult to understand what happens in a family business if we do not consider the temporal dimension (Parada et al., 2019). Family businesses are defined by
The adoption of governance mechanisms 
the desire for transgenerational sustainability, which leads to successive generations being involved in the business.

Broadly speaking, lifecycles in businesses are related to start-up, growth and maturity phases, and this means there is an urgent need in terms of business governance. In fact, life cycles in the business institution are shorter than those in the family institution. However, family businesses follow a completely different timeframe based on generations' lifecycle and involve a lag between generations of around 25-30 years. Having more generations does not necessarily mean higher complexity, because other factors can influence this complexity (e.g. having many descendants versus one descendant). Researchers and academics tend to prescribe family councils as a useful tool for the family and the firm (Gray, 2007) and to cope with more complex generational stages (e.g. sibling partnership, or cousin consortiums, and beyond) (Lansberg, 2007; Moore and Juenemann, 2008). This means that a family council may be eventually created 20-30 years after a business is founded. Therefore, developing an appropriate governance structure may diminish the effects of increasing family and ownership complexity (Jaffe and Lane, 2004). Hence, family governance may be adopted when family businesses move beyond the founding generation to a sibling partnership, and becomes even more necessary when it moves beyond this, to a cousin consortium (Gersick et al., 1997; Lansberg, 1999; Steier, 2001).

The family constitution or protocol is a tool that includes a set of rules that are employed when there is a need to formalize the role of the family in the business, as it moves beyond the founder stage to more complex relationships between members of the same family, and between family members and the business (Aronoff and Ward, 1996; Vilaseca, 2002). Practitioner-oriented literature also promotes the benefits of having family councils with clear sets of rules in the later stages of the family business cycle (Lansberg, 2007; Moore and Juenemann, 2008).

It can thus be inferred from the diverse literature on the topic that family businesses may follow a specific sequence in the adoption of governance structures (e.g. Aronoff and Ward, 1996; Gersick et al., 1997; Gimeno et al., 2010; Neubauer and Lank, 1998; Nordqvist et al., 2014). The time lag between the two systems suggests that family businesses may first introduce business governance mechanisms, and later family governance ones. This leads us to explore and uncover: How are governance structures adopted and developed in family firms?

\section{Usefulness of governance structures and ceremonial adoption}

A different stream of institutional theory suggests that organizations are capable of deciding to what extent they will respond to institutional pressures (c.f. Heugens and Lander, 2009). When organizations are confronted with conflicting demands between a search for legitimacy and efficiency achievement, in other words, when rationalized myths are not in line with what the organization sees as an efficient solution (Boxenbaum and Jonsson, 2008), they tend to decouple structure from practice to solve this problem (Meyer and Rowan, 1977). Decoupling means that organizations may adopt governance structures ceremonially (only on paper) to comply with institutional pressures while carrying on their business as usual (Boxembaum and Jonsson, 2008). For Meyer and Rowan (1977), decoupling involves disconnecting structure from practice, as the practice is "determined by perceived efficiency concerns and structure results from institutional pressure for conformity" (Boxenbaum and Jonsson, 2008, p. 81). Scott (1998) suggests that decoupling reflects "the overriding [imperative] of all systems. . . to maintain the integrity and continuity of the system itself. .. including the stability of informal[routines and power relationships] within the organization" (Scott, 1998, p. 117, as cited in Zajac and Westphal, 2004), as "institutionalized organizations seek to avoid inspection and evaluation by internal managers and external constituents" (Meyer and Rowan, 1977, p. 359). 
We contend that institutional pressures may play a key role in explaining the way governance structures are set up in family businesses. Institutional pressures may condition (DiMaggio and Powell, 1983) the pattern through which family businesses choose to set up and develop their governance structures, as they seek for legitimacy and to fit in with their environment and context. We also suggest that the perceived usefulness of these governance structures may condition to what extent they are effectively used.

While family businesses may be influenced by institutional pressures that drive them to adopt certain practices, it is also true that organizations and or/individuals may reflect upon the institutional pressures they are exposed to, and this may influence the extent to which they will apply them. Tolbert and Zucker (1996) point out that symbolic adoption arises if there is a degree of consensus among members about the value of a practice. When the practice is perceived as positive and valuable, this is reflected in the internalization process. These positive perceptions are important because of their "action-generating" properties, which facilitate the initial adoption of the practice as well as its persistence and stability over time (Tolbert and Zucker 1996). Therefore, for Kostova and Roth (2002), implementation and internalization reflect the "depth" of adoption of the practice.

Given the paradox described above, our second research question is as follows: once adopted, how do family businesses perceive these governance structures?

\section{Method}

Our article aims at exploring how governance structures are adopted and developed in family firms. We suggest that family businesses may follow a specific pattern given their exposure to institutional pressures. Therefore, we aim to determine and describe patterns in the creation of governance structures in family businesses, and to observe if a sequence is followed when creating the governance bodies that constitute the governance structure of the family business. For this purpose, this study applies the Mokken Scale Analysis using version 3.0 of the MSP software program (Moleenar et al., 1998). Using Mokken Scales, it is possible to test the scalability of a set of dichotomous items and estimate the coefficient of reliability (Moolenar et al., 1998). This method is particularly suitable for this study, as it allows us to discover the sequence through which certain events have occurred over time, thus shedding light on the sequential order in which family businesses adopt various governance structures. In fact, Mokken Scale analysis (Sijtsma and Molenaar, 2002) has been used in other studies for acquisition pattern analysis (cf. Paas and Molenaar, 2005). Paas (2009) used it for acquisition patterns in the banking industry, suggesting that "if the Mokken scale model fits the data on ownership of financial products, then products owned by a greater proportion of respondents are usually acquired before less commonly owned products" (pp. 808-809), suggesting the existence of a specific order of acquisition over time.

MSP is a software that allows to perform Mokken Scale Analysis, a probabilistic, nonparametric scale analysis that can handle three or more rank-ordered response categories per item. To indicate a hierarchical pattern, the result has to show a consistent single pattern. This means that family businesses would have created A before B and B before C. Only a few instances should be found where $\mathrm{C}$ was created without previously having created $\mathrm{B}$ and $\mathrm{A}$. The Mokken Scale analyses the sequential structure (Mokken, 1997; Mokken and Lewis, 1982; Moleenar et al., 1998). To test the fit of the Mokken Scale model to the creation of governance structure, we use three measures based on Loevinger's $H$ coefficient. The $H$ coefficient is equivalent to Chronbach's Alpha coefficient of reliability. (1) Loevinger's (1948) scalability coefficient $(H)$ measures the degree to which subjects can be accurately ordered using $k$ items (Moleenar et al., 1998). The larger the $\mathrm{H}$ is, the more confidence can be held in the ordering of subjects along the latent scale (Mokken et al., 1986). H coefficient can be used for both the scale
The adoption of governance mechanisms

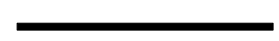


and for each item. Hence, (2) $H_{i}$ is used for individual items (Sijtsma and Meijer, 1992), where the larger $H_{i}$ is (positive values), the more confidence can be attributed to the invariant ordering of items $H_{i j}$ for item pairs, and $H$ for a set of items as a whole. (3) $H_{i j}$ coefficient can be understood as the sum of single errors or violations in the deterministic model. For a set of items to be accepted as a scale, all $H_{i j}$ must be greater than 0.0 , and all $H_{i}$ must be greater than 0.30 . In that case, $H$ will be greater than or equal to 0.30 . If $H$ is lower than 0.30 , the scale is weak. If $H$ is higher than 0.4 , the scale is strong; and if it is higher than 0.5 , it is very strong.

Thus, according to Mokken (1971), a set of items forms a Mokken Scale if: $H \geq 0.3$; All $H_{i} \geq 0.3$; All $H_{i j} \geq 0 ; Z \geq 1.65$; All $Z_{i} \geq 1.65 ; H^{t} \geq 0.3$ and $H_{i}^{t}<0$ is less than $10 \%$.

\section{Sample and data collection}

This study relied on an existing dataset of 1,488 Spanish family businesses. Data for this analysis derives from the FBK (Family Business Knowledge) database. The information was collected between 2004 and 2008 for a project examining the characteristics of Spanish Family Businesses, highlighting strengths and risks. Family businesses participating in this survey were invited via FBK, ESADE Business School and the IEF (Instituto de la Empresa Familiar), and all their regional chapter associations. The survey was completely anonymous. In exchange for participating in the survey, companies received an extended report analyzing their characteristics, risks, strengths, and opportunities. Thus, family businesses interested in receiving feedback about their current situation and future risks and opportunities were motivated to take part in the study.

While the questionnaire covered an array of themes, a key topic included in the questionnaire was the existence of governance mechanisms in the family business, and whether they were useful or not. For this article, we focused on four variables, which form our latent dimension, called: "Governance Structure". These variables are (1) Executive Committee, (2) Board of Directors, (3) Family Council, and (4) Family Constitutions. All four variables were categorized as binary: 1 the company has the governance mechanism and 0 the company does not have it. In addition to the governance mechanisms, the variable related to the usefulness of the governance mechanism was also categorized as binary: 1 (it is useful), 0 (not useful).

The sample includes 1,488 companies with ages ranging from 10 to more than 100 years $15 \%$ of the sample is less than thirty years old. $27 \%$ of the companies are between 30 and 49 years old. $19 \%$ of them are between 50 and 100 years old. $4 \%$ are more than a century old. The sample also includes a wide range of companies of different sizes measured by the number of employees. $62 \%$ of the sample employs less than 100 people. $30 \%$ of the sample employs between 100 and 499 employees. $5 \%$ of the sample employs between 5,000 and 999 employees, and $3 \%$ employs more than $3 \%$. Regarding the dominant generation, our sample includes $52 \%$ of the companies who are in the founding generation, 325 are in the second generation and $14 \%$ are in the third generation and beyond. Given that time is important, the age of the company gives some hints on how the business cycle affects the adoption of governance structures. Likewise, the fact that the usefulness of such structures plays a key role in our study, size is also an indicator as to when governance might be needed.

\section{Data analysis and results}

We used SPSS 18.0 to organize the data and define the main variables. At this stage, we also removed some cases, because there were missing values associated with our main variables. To run the Mokken Scale analysis, we revised the data to make sure all relevant items (existence of board of directors, family council, family constitution and executive committee) were dichotomous (dummy) yes/no variables. Consistent with our theoretical framing, the 
variables chosen for the Mokken study were: (1) Executive Committee, (2) Board of Directors, (3) Family Council and (4) Family Constitution. This previous work made it possible for us to export the data into MSP 3.0 for further analysis of the scalability of the items under study. MSP is a standalone program that implements the Mokken Scale procedure (explained in the methods section). With this program we were able to build the sub-scales based on Loevinger $H$ coefficients. After running the program, the results show whether these variables belong to the latent variable we operationalized as "governance structure" (whether the four mechanisms form a scale) and, if so (if the model is satisfied), simple sum scores are used to order the items stochastically upon the underlying variable (Hemker et al., 1997).

Tables 1 and 2 present the results of the conducted analysis.

Table 1 shows that there is "one final scale," which means that the "four items" included in the analysis (executive committee, board of directors, family council and family constitution) do constitute one single scale. The following three parameters in the table (lower-bound, adjusted Alpha and Critical $Z$ ) are statistics, which indicate the level of confidence. The lowerbound parameter allows us to define whether the items belong together when the scalability coefficient is higher than the lower-bound parameter (Sijtsma and Molenaar, 2002). $Z$ tests analyze Motonicity. Alpha indicates the confidence level.

Table 2 shows the scalability of the items. Items are ordered in accordance to their mean, which represent the degree of difficulty: the higher the mean, the lower the difficulty. Scale Coefficient or Loevinger's coefficient $H=0.4 \geq 0.4$. Thus, condition one applies. The items that form the governance structure are scalable with a high degree of confidence. $H_{i}$ coefficients for the four single items are also higher than 0.3 and 0.4 , which shows that a high level of confidence can be assigned to the invariant ordering of the items.

The items are ordered according to their difficulty, as expressed by the item mean scores. All $H_{i}$ s were greater than or equal to 0.30 . As a consequence, the main results suggest that family businesses follow a pattern when creating their governance structures. For instance, before having a family council, they have previously created the executive committee, and before creating the executive committee, they have first created the board of directors. Finally, for writing a family constitution, family businesses have previously created the three preceding governance arenas (See Figure 1).

\begin{tabular}{llr}
\hline & Value \\
\hline Final scale & 1 & \\
Number of items & 4 & \\
Number of steps & 3 & Table 1. \\
Lower bound & 0.30 & Output MSP analysis: \\
Adjusted alpha & 0.0056 & main results \\
Critical $Z$ & 2.54 & \\
\hline
\end{tabular}

The adoption of governance mechanisms $\overline{-10}$ 
The results presented reveal a general pattern in the sequence that family firms follow to structure their corporate governance. However, this does not mean that alternative sequences may not be present in some specific cases. The results do not imply that it is impossible to have, for example, a family constitution without having a family council or a board of directors. However, few instances are found where this situation has arisen.

After unpacking the pattern, we returned to the data to analyze whether family businesses found the mechanism useful or not. Table 3 shows descriptive data about the results.

It is interesting to note that, from the wide sample of Spanish family businesses, more than $40 \%$ of those companies do not consider the board of directors to be useful, even though they have created one. On the contrary, we observe that more than $80 \%$ of family businesses that have established a family council consider it to be beneficial. Finally, the executive committee seems to be the most useful mechanism. Yet, it is also remarkable that a considerable amount $(20 \%)$ of family businesses that implement family councils consider this mechanism to be not useful, while $10 \%$ of family businesses perceive that the executive committee they have is not useful.

\section{Conclusions and implications}

This study aimed to explore how are governance structures adopted and developed in family firms. In light of our theoretical framework we looked at the sequential order through which governance structures are adopted in family businesses, and whether controlling owners perceive these governance structures to be useful. Drawing on institutional theory, this article offers a plausible explanation as to why family businesses follow a specific pattern in adopting their governance structures and why these governance structures are not achieving their theorized role in increasing the competitiveness of family businesses.

Our results show the existence of a specific pattern when establishing governance structures in family businesses. As shown in Figure 1, family businesses start by adopting business governance mechanisms (board of directors and executive committee) and then adopt family governance mechanisms (family council, and family constitution). The results

Figure 1.

Process of developing governance structures in family businesses

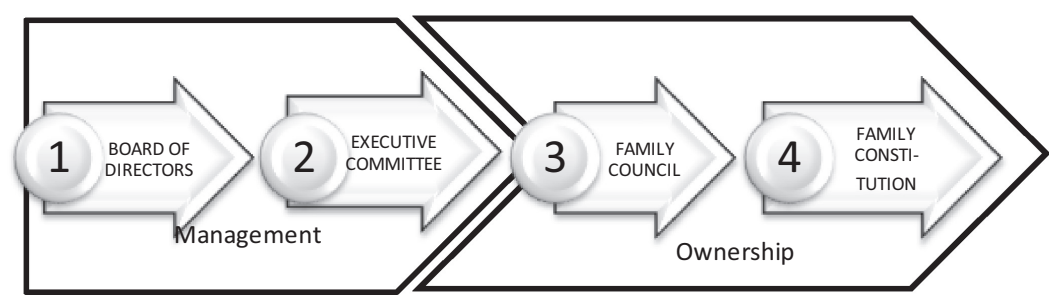

\section{Table 3.}

Contingency table existence vs usefulness of governance mechanisms

\begin{tabular}{lccc}
\hline Existence & & & Usefulness \\
& & No & Yes \\
\hline Board of directors & No & $71 \%$ & $29 \%$ \\
& Yes & $40 \%$ & $60 \%$ \\
Family council & No & $71 \%$ & $29 \%$ \\
& Yes & $17 \%$ & $83 \%$ \\
Executive committee & No & $87 \%$ & $13 \%$ \\
& Yes & $9 \%$ & $91 \%$
\end{tabular}


suggest that the process of creating governance structures in family businesses may start with the board of directors and the executive committee, and then move on to family governance mechanisms. As explained by Gersick and Feliu (2014, p. 199) “. . . nearly all legal systems specify some kind of board of directors as the ultimate governance authority in a corporation (Mintzberg, 1983; Fama and Jensen, 1983; Cadbury, 1992, 1999; Monks and Minow, 1996)." Therefore, following institutional theorists, it could be argued that pressured by coercive forces (DiMaggio and Powell, 1983), family businesses may create the board of directors as the first mechanism in their governance structure. Moreover, the perception of the legitimacy of family businesses may increase when a more sophisticated body is in place, hence diminishing the stigma of being perceived as an unprofessional company. Accordingly, family businesses may also set up the board of directors as a first body for governing the family business and to mimic the practices of quoted companies, this being a widely recognized model of efficiency. In addition, the board of directors has been widely recommended by practitioners and scholars in the family business field (e.g. Neubauer and Lank, 1998; Samara et al., 2019a; Ward, 1991), following the publicly quoted companies' structure in some way (Gimeno, 2010), hence showcasing normative institutional pressures. Taken together, mimetic, coercive, and normative forces, such as professional associations and national jurisdictions, may force family businesses to start with the board of directors. In line with Parada et al. (2010), we suggest that institutional pressures stemming from such institutions condition the adoption of governance structures in family businesses.

The second step taken by family businesses is the creation of an executive committee. This may be related to the fact that, over time, business complexity increases, thus requiring companies to cope with growth and organizational change (Barry, 1989). Therefore, a new institution is needed to manage the company and to develop the management team. This is in line with the overlapping three-circle model (Gersick et al., 1997; Taguiri and Davis, 1992; Ward, 1987), where each institution has its own sphere: the ownership represented by the board of directors, the family represented by the family council, and the management represented by the executive committee.

The final steps for creating the governance structure revolve around setting up the family governance structures, whereby the family council is created first, followed by the establishment of the family constitution. In fact, one of the tasks of the family council is to develop the family constitution, and therefore it may be the last phase in the developmental process of a governance structure. This governance body has increasingly become a "must" in family businesses (Melin and Nordqvist, 2007), for dealing with any complexities that may arise in the family sphere. The creation of the family constitution as the last item in the process of developing a governance structure may indicate that, in most cases, this process of writing a constitution is done by consensus. Since the family governance mechanisms are idiosyncratic to each family, they are therefore less subject to institutional pressures, which explain why they are adopted last, as shown in Figure 1.

Given the increasing institutionalization in the area of family businesses, practitioners and academics recommend adopting various governance structures to manage family and business complexities (Melin and Nordqvist, 2007). Moreover, having the four mechanisms has been widely prescribed as essential for creating effective governance structures (Ward, 1991; Neubauer and Lank, 1998). Yet, these governance structures have not always been successful in achieving their theorized role of benefitting the business and family systems.

Interestingly, results as to whether these mechanisms are considered useful by family businesses reveal that institutional pressures (DiMaggio and Powell, 1983) may exert most influence when establishing the first mechanism, the board of directors. In more than $40 \%$ of the firms studied, the board of directors is considered not useful. Hence, we interpret this finding by suggesting that, when organizations face conflicting demands in their quest for legitimacy and efficiency, they tend to decouple structure from practice to solve this problem
The adoption of governance mechanisms 
(Meyer and Rowan, 1977). In other words, family businesses may comply with institutional pressures, thus adopting a governance structure that allows them to appear professionalized (Goffmann, 1967) in front of external stakeholders. As such, this adoption can become ceremonial (Boxembaum and Jonsson, 2008) and not be used effectively. As a result, the theorized efficiency and effectiveness of business governance mechanisms in achieving certain goals becomes diluted, and they become additional unnecessary burdens that are not capitalized on.

Results show a high degree of agreement between the existence and usefulness of family councils and executive committees. The creation of family councils and, eventually, family constitutions, may be influenced by normative and mimetic forces, as some family businesses may implement them to comply with the best practices prescribed by academics, consultants and/or associations (Abrahamson, 1991; Sahlin and Wedin, 2008).

\section{Contributions}

This study contributes to the family business literature in several ways. First, we show that family firms adopt the four prescribed governance structures (board of directors, family council, family constitution, and executive committee) in a specific order. The family business starts with the adoption of business governance structures in response to coercive, mimetic, and normative institutional forces. However, they tend to decouple adoption from effective implementation, as these governance mechanisms remain ceremonially adopted and not effectively used. As governance is considered to be a set of formal decisions to control the organization and the behavior of its members (Steier et al., 2015), the article suggests that there is a need to couple adoption with effective implementation if these structures are to achieve their desired role. While most research has focused on how the presence of certain governance mechanisms, such as the presence of independent directors on boards, affects performance (e.g. Samara and Berbegal-Mirabent, 2018), this study takes a step back and highlights the importance of understanding the process underlying the creation of business governance mechanisms as a critical step for understanding when governance mechanisms can improve the performance of family businesses. Doing so, this article echoes the growing calls for a nuanced discussion of governance structures, and consideration as to whether "governance choices have to result in action, such as strategic change, before they can have performance implications" (Brunninge et al., 2007, p. 296).

Second, by drawing on institutional theory as the main theoretical framework, we enrich the family business literature by adding new insights to the discussion related to governance. Few studies have used this theoretical framework in family businesses (for an exception, see Leaptrott, 2005; Melin and Nordqvist, 2007; Parada et al., 2010), despite it being considered as a powerful theoretical lens that can explain various family business behaviors (e.g. Moores, 2009). Therefore, this study opens up new avenues for family business research to investigate when and why family businesses adopt certain governance structures and mechanisms, such as inviting independent directors to sit on the board (Melin and Nordqvist, 2007; Sharma and Nordqvist, 2008).

Third, as there is no single recipe that can serve the multiple needs of different family businesses, this indicates that family businesses may need diverse levels of development and order when setting up their governance structures (Nordqvist et al., 2014; Samara et al., 2019b). Accordingly, this study constitutes an important point of demarcation for researchers and practitioners interested in examining the effectiveness of governance structures in family firms. We show that an important pre-requisite for examining the effectiveness of governance structures is to start by investigating whether these structures are actually being used or are only adopted ceremonially. 


\section{Limitations and avenues for future research}

While we believe that the study has various strengths, such as the use of an innovative research method in the field and the link between governance and institutional theory in the context of family businesses, we also acknowledge some limitations inherent in the design of the investigation, and further studies could enrich this line of research. Restrictions may arise from the quantitative sample, as the study only comprises family businesses located in Spain. Therefore, other variables may play an important role, such as institutional pressures related to national culture, or national/regional regulations. Replicating the quantitative study in other countries could shed light on any differences that may arise in the process of developing governance structures. This could take the form of conducting comparative studies among countries and among cultures and institutional environments (Samara et al., 2019b).

We also used an existing database, which limited our flexibility to operationalize variables from scratch, to refine the concepts we want to study. Accordingly, the motivations for adopting governance practices have been indirectly identified by inferring them from their usefulness. Further research could take the form of exploring the development of governance structures in more depth. By performing a qualitative study we may able to find different subpatterns in the development of governance structures, given the idiosyncratic behavior and characteristics of family businesses, since they are unique (Kets de Vries et al., 2007), and governance structures tend to capture these idiosyncrasies and heterogeneity among family businesses (Chrisman et al., 2018). Moreover, a qualitative approach may uncover the motivations behind the adoption of governance structures, and the interplay between institutional pressures and efficiency gains could be revealed.

While these findings demonstrate the existence of a pattern in the development of governance structures in family businesses, which contributes in different ways to the family business literature, these results show only the tip of the iceberg. Therefore, the research could go further by exploring why this happens in more depth, utilizing qualitative case studies. This research opens up new questions for research on the family business in general and concerning institutionalization in particular, by adding the process dimension. Understanding the pattern that family businesses follow in creating their governance structure may lead to a deeper understanding of the institutionalization of the family businesses. This finding may be further explored by employing qualitative analysis to understand why these governance practices and structures have been created, and what are the consequences of this institutionalization process (e.g. Greenwood and Hinings, 1996; Ocasio, 1999).

For researchers, further lines of research could also include questions such as: are these patterns in governance structures a consequence of the process of institutionalization, given the pressures, mimetic and coercive forces (Di Maggio and Powell, 1983) exercised by networks, associations and even researchers in the field, leading somehow to a homogenization of family businesses? What are the requirements for implementing these governance structures, and at what pace should they be implemented, to achieve performance and efficiency?

As this study sheds light on a sequence for creating the governance structure, the main issue to be explored is: how is the transition from one phase to the next? Consequently, this leads to the hypothesis that different family businesses may require different types of governance structures, depending on their family involvement, their values, their goals and strategies (Sharma and Nordqvist, 2008).

Likewise, the stage at which a company finds itself, in terms of family and business complexity, may condition the level of development in the structure to be in line with its complexity (Gimeno et al., 2010). In other words, not all family businesses may need the same level of development in their governance structures (Melin and Nordqvist, 2007). Thus, depending on many factors, which may be worth studying, companies may be in a first-level
The adoption of governance mechanisms 
or a fourth-level governance structure. This also highlights the need to explore in more depth the timeframes for developing these governance structures and conducting a more in-depth analysis of the family business' resources and capabilities to manage growth and change.

Finally, these findings could bring research closer to "how things are done" and therefore raise practitioners' interest in family business research. The main questions that arise in this line are: are these governance bodies the only ones that apply to family businesses? What is the best way to develop these structures? How can this be developed, and what is the pace and the requirements for doing so?

\section{References}

Abrahamson, E. (1991), "Managerial fads and fashions: the diffusion and rejection of innovations", Academy of Management Review, Vol. 16, pp. 586-612.

Aparicio, G., Basco, R., Iturralde, T. and Maseda, A. (2017), “An exploratory study of firm goals in the context of family firms: an institutional logics perspective”, Journal of Family Business Strategy, Vol. 8 No. 3, pp. 157-169.

Aronoff, C. and Ward, J. (1996), Family Business Governance: Maximizing Family and Business Potential, Family Enterprise Publishers, Marietta, GA.

Barry, B. (1989), "The development of organization structure in the family firm", Family Business Review, Vol. 2, pp. 293-315.

Boxenbaum, E. and Jonsson, S. (2008), "Isomorphism, diffusion and decoupling in royston Greenwood, christine oliver", in Sahlin, K. and Roy, S. (Eds), The Sage Handbook of Organizational Institutionalism, Sage Publishing, London, pp. 78-98.

Brunninge, O., Nordqvist, M. and Wiklund, J. (2007), "Corporate governance and strategic change in SMEs: the effects of ownership, board structure and top management teams", Small Business Economics, Vol. 29, pp. 295-308.

Cadbury, A. (Ed.) (1992), Report of the Committee on "The Financial Aspects of Corporate Governance, Gee \& Co, London.

Cadbury, A. (1999), "What are the trends in corporate governance? How will they impact your company?”, Long Range Planning, Vol. 32 No. 1, pp. 12-19.

Carney, M. (2005), "Corporate governance and competitive advantage in family-controlled businesses", Entrepreneurship: Theory and Practice, Vol. 29 No. 3, pp. 349-365.

Chandler, A.D. (1962), Strategy and Structure: Chapters in the History of American Industrial Enterprises, MIT Press, Cambridge. MA.

Chrisman, J.J., Chua, J.H., Le Breton-Miller, I., Miller, D. and Steier, L.P. (2018), "Governance mechanisms and family firms", Entrepreneurship: Theory and Practice, Vol. 42 No. 2, pp. 171-186.

Corbetta, G. and Salvato, C.A. (2004), “The board of directors in family firms: one size fits all?", Family Business Review, Vol. 17 No. 2, pp. 119-134.

Corbetta, G., Gnan, L. and Montemerlo, D. (2002), Governance System and Company Performance in Italian SMEs, Università Bocconi, Milano, Working Paper Isea.

Daily, C.M., Dalton, D.R. and Cannella Jr, A.A. (2003), "Corporate governance: decades of dialogue and data", Academy of Management Review, Vol. 28 No. 3, pp. 371-382.

Di Maggio, P.J. and Powell, W.W. (1983), "The iron cage revisited: institutional isomorphism and collective rationality in organizational fields", American Sociological Review, Vol. 48, pp. 147-160.

DiMaggio, P.J. (1988), "Interest and agency in institutional theory", in Zucker, L.G. (Ed.), Institutional Patterns and Organizations: Culture and Environment, 3-21, Ballinger, Cambridge, MA. 
Fama, E.F. and Jensen, M.C. (1983), "Separation of ownership and control", The Journal of Law and Economics, Vol. 26, pp. 301-326.

Freeman, E. (1984), Strategic Management: A Stakeholder Approach, Pitman, Boston MA.

Gallo, M.A. and Kenyon-Rouvinez, D. (2005), The Importance of Family and Business Governance in Family Busines, Vols 45-57, Palgrave Macmillan, London.

Gedajlovic, E. and Carney, M. (2010), "Markets, hierarchies, and families: toward a transaction cost theory of the family firm", Entrepreneurship: Theory and Practice, Vol. 34 No. 6, pp. 1145-1172.

Gersick, K.E. and Feliu, N. (2014), "Governing the family enterprise: practices, performance, and research", in Melin, L., Nordqvist, M. and Sharma, P. (Eds), The SAGE Handbook of Family Business, pp. 196-225.

Gersick, K.E., Davis, J.A., Hampton, M.M. and Lansberg, I. (1997), Generation to Generation: Lifecycles of the Family Business, Harvard Business School Press, Boston MA.

Gimeno, A., Labadie, G., Saris, W. and Mendoza, X. (2006), "Internal factors of family business performance: an integrated theoretical model", in Poutziouris, P., Smyrnios, K. and Klein, S. (Eds), Handbook of Research on Family Businesses, Edward Elgar, Cheltenham, pp. 145-164.

Gimeno, A., Baulenas, G. and Coma-Cros, J. (2010), Family Business Models, Vols 57-77, Palgrave Macmillan, London.

Goel, S., Jussila, I. and Ikäheimonen, T. (2014), "Governance in family firms: a review and research agenda", in Melin, L., Nordqvist, M. and Sharma, P. (Eds), The SAGE Handbook of Family Business, pp. 226-248.

Goffmann, E. (1967), Interaction Ritual, Garden City, New York.

Granovetter, M. (1985), "Economic action and social structure: the problem of embeddedness", American Journal of Sociology, Vol. 91, pp. 481-510.

Gray, L.P. (2007), "The three forms of governance: a new approach to family wealth transfer and asset protection, Part I", The Journal of Wealth Management, Vol. 10 No. 2, pp. 10-19, Moore.

Greenwood, R. and Hinings, C. (1996), "Understanding radical organizational change: bringing together the old and the new institutionalism", Academy of Management Review, Vol. 214, pp. 1022-1054.

Hemker, B.T., Sijtsma, K., Molenaar, I.W. and Junker, B.W. (1997), "Stochastic ordering using the latent trait and the sum score in polytomous IRT models", Psychometrika, Vol. 62 No. 3, pp. 331-347.

Heugens, P. and Lander, M.W. (2009), "Structure! Agency! (and other quarrels): a meta-analysis of institutional theories of organization", Academy of Management Journal, Vol. 52 No. 1, pp. 61-85.

Jaffe, D.T. and Lane, S.H. (2004), "Sustaining a family dynasty: key issues facing complex multigenerational business-and investment-owning families", Family Business Review, Vol. 17 No. 1, pp. 81-98.

Keasey, K., Thompson, S. and Wright, M. (2005), Corporate Governance: Accountability, Enterprise and International Comparisons, Wiley, London.

Kets de Vries, M.F., Carlock, R. and Florent-Treacy, E. (2007), Family Business on the Couch, John Wiley \& Sons, West Sussex.

Kostova, T. and Roth, K. (2002), "Adoption of an organizational practice by the subsidiaries of the MNC: institutional and relational effects", Academy of Management Journal, Vol. 45, pp. 215-233.

Lansberg, I.S. (1983), "Managing human resources in family businesses: the problem of institutional overlap", Organizational Dynamics, Vol. 12 No. 1, pp. 39-46.

Lansberg, I. (1999), Succeeding Generations: Realizing the Dreams of Families in Business, Harvard Business School Press, Boston, MA. 
Lansberg, I. (2007), "The tests of a prince", Harvard Business Review, Vol. 85 No. 9, p. 92.

Le Breton-Miller, I. and Miller, D. (2006), "Why do some family businesses out-compete? Governance, long-term orientations, and sustainable capability", Entrepreneurship: Theory and Practice, Vol. 30 No. 6, pp. 731-746.

Leaptrott, J. (2005), "An institutional theory view of the family business", Family Business Review Vol. 18 No. 3, pp. 215-228.

Loevinger, J. (1948), “The technic of homogeneous tests compared with some aspects of 'scale analysis' and factor analysis", Psychological Bulletin, Vol. 45 No. 6, p. 507.

McClelland, D.C. (1962), "Business drive and national achievement”, Harvard Business Review Vol. 40, pp. 99-112.

Melin, L. and Nordqvist, M. (2007), "The reflexive dynamics of institutionalization: the case of the family business", Strategic Organization, Vol. 54, pp. 321-333.

Meyer, J.W. and Rowan, B. (1977), "Institutionalized organizations: formal structure as myth and ceremony", American Journal of Sociology, Vol. 83, pp. 340-363.

Miller, D. and Le Breton-Miller, I. (2007), "Kicking the habit: broadening our horizons by studying family businesses", Journal of Management Inquiry, Vol. 161, pp. 27-30.

Miller, D. and Le-Breton-Miller, I. (2005), Managing for the Long Run: Lessons in Competitive Advantage from Great Family Business, Harvard Business School Press, Boston, MA.

Mintzberg, H. (1983), Power in and Around Organizations, Prentice- Hall, Englewood Cliffs, NJ.

Mokken, R.J. (1971), A Theory and Procedure of Scale Analysis, Mouton, The Hague.

Mokken, R.J. (1997), "Nonparametric models for dichotomous responses", in Van rer Linden, W.J. and Hambleton, R.K. (Eds), Handbook of Modern Item Response Theory, Springer-Verlag, New York, NY.

Mokken, R.J. and Lewis, C. (1982), "A nonparametric approach to the analysis of binary item responses”, Applied Psychological Measurement, Vol. 63, pp. 417-430.

Mokken, R.J., Lewis, C. and Sijtsma, K. (1986), "Rejoinder to 'the mokken scale: a critical discussion”, Applied Psychological Measurement, Vol. 10 No. 3, pp. 279-285.

Molenaar, I.W., Debets, P., Sijtsma, K. and Hemker, B.T. (1998), A Program for Mokken Scale Analysis for Polytomous Items: Version 3.0, ProGAMMA, Groningen.

Monks, R. and Minow, N. (1996), Watching the Watchers: Corporate Governance for the 21st Century, Blackwell Publishers, Cambridge.

Moore, J. and Juenemann, T. (2008), "Good governance is essential for a family and its business", Family Business, Summer, pp. 63-66.

Moores, K. (2009), "Prologue. Researching family business: an interview with professor danny miller", Journal of Management and Organization, Vol. 15, pp. 278-281.

Mustakallio, M., Autio, E. and Zahra, S.A. (2002), "Relational and contractual governance in family firms: effects on strategic decision making", Family Business Review, Vol. 15 No. 3, pp. 205-222.

Neubauer, F. and Lank, A.G. (1998), The Family Business - its Governance for Sustainability, MacMillan Business, London.

Nordqvist, M. and Melin, L. (2002), "The dynamics of family businesses: an institutional perspective on corporate governance and strategic change", In Fletcher, D. (Ed.), Understanding the Small Family Firm, Routledge, London.

Nordqvist, M., Sharma, P. and Chirico, F. (2014), "Family firm heterogeneity and governance: a configuration approach”, Journal of Small Business Management, Vol. 52 No. 2, pp. 192-209.

Ocasio, W. (1999), "Institutionalized action and corporate governance: the reliance on rules of CEO succession", Administrative Science Quarterly, Vol. 44, pp. 384-416. 
Paas, L.J. (2009), "Acquisition pattern analysis for evolutionary database marketing", Service Industries Journal, Vol. 29 No. 6, pp. 805-812.

Paas, L.J. and Molenaar, I.W. (2005), "Analysis of acquisition patterns: a theoretical and empirical evaluation of alternative methods", International Journal of Research in Marketing, Vol. 22 No. 1, pp. 87-100.

Parada, M.J., Nordqvist, M. and Gimeno, A. (2010), "Institutionalizing the family business: the role of professional associations in fostering a change of values", Family Business Review, Vol. 23 No. 4, pp. 355-372.

Parada, M.J., Samara, G., Dawson, A. and Bonet, E. (2019), "Prosperity over time and across generations: the role of values and virtues in family businesses", Journal of Organizational Change Management, in press.

Perez-Gonzalez, F. (2006), "Inherited control and firm performance", The American Economic Review. Vol. 965, p. 1559.

Poza, E.J. (2007), Family Business, Thomson South-Western, Mason, OH.

Sahlin, K. and Wedlin, L.. (2008), "Circulating ideas: imitation, translation and editing”, in Greenwood, R., Oliver, C., Sahlin, K. and Suddaby, R. (Eds), The Sage Handbook of Organizational Institutionalism, Sage, Thousand Oaks, CA, pp. 218-242.

Samara, G. and Arenas, D. (2017), "Practicing fairness in the family business workplace", Business Horizons, Vol. 60 No. 5, pp. 647-655.

Samara, G. and Berbegal-Mirabent, J. (2018), "Independent directors and family firm performance: does one size fit all?", The International Entrepreneurship and Management Journal, Vol. 14 No. 1, pp. 149-172.

Samara, G. and Paul, K. (2019), "Justice versus fairness in the family business workplace: a socioemotional wealth approach", Business Ethics: A European Review, Vol. 28 No. 2, pp. 175-184.

Samara, G., Jamali, D. and Lapeira, M. (2019a), "Why and how should she make her way into the family business boardroom?”, Business Horizons, Vol. 62 No. 1, pp. 105-115.

Samara, G., Jamali, D. and Parada, M.J. (2019b), Antecedents and outcomes of bifurcated compensation in family firms: a multilevel view", Human Resource Management Review, in press.

Schwartz, M.A. and Barnes, L.B. (1991), "Outside boards and family businesses: another look", Family Business Review, Vol. 43, pp. 269-285.

Scott, W.R. (1998), Organizations: Rational, Natural and Open Systems, 4th ed., Prentice-Hall, Englewood Cliffs, NJ.

Scott, W.R. (2008), Institutions and Organizations: Ideas and Interests, 3rd ed., Sage, Thousand Oaks, CA.

Sharma, P. and Nordqvist, M. (2008), "A classification scheme for family businesses: from family values to effective governance to firm performance", in Tapies, J. and Ward, J.L. (Eds), Family Values and Value Creation: How Do Family-Owned Businesses Foster Enduring Values, Palgrave Macmillan Publishers, New York.

Sharma, P., Melin, L. and Nordqvist, M. (2014), "Introduction: scope, evolution and future of family business studies", in Melin, L., Nordqvist, M. and Sharma, P. (Eds), The SAGE Handbook of Family Business, pp. 1-23.

Sijtsma, K. and Meijer, R.R. (1992), "A method for investigating the intersection of item response functions in Mokken's nonparametric IRT model", Applied Psychological Measurement, Vol. 16 No. 2, pp. 149-157.

Sijtsma, K. and Molenaar, I.W. (2002), An Introduction to Nonparametric Item Response Theory. Measurement Methods for Social Sciences, Vol. 5, Sage, Newbury Park.

Steier, L. (2001), "Family firms, plural forms of governance, and the evolving role of trust", Family Business Review, Vol. 14 No. 4, pp. 353-368. 
Steier, L.P., Chrisman, J.J. and Chua, J.H. (2015), "Governance challenges in family businesses and business families”, Entrepreneurship: Theory and Practice, Vol. 39 No. 6, pp. 1265-1280.

Suchman, M.C. (1995b), "Managing legitimacy: strategic and institutional approaches", Academy of Management Review, Vol. 20, pp. 571-610.

Taguiri, R. and Davis, J.A. (1992), "On the goals of successful family companies", Family Business Review, Vol. 51, pp. 263-281.

Tolbert, P.S. and Zucker, L.G. (1983), "Institutional sources of change in the formal structure of organizations: the diffusion of civil service reform, 1880-1935", Administrative Science Quarterly, Vol. 28, pp. 22-39.

Tolbert, P. and Zucker, L. (1996), "The institutionalization of institutional theory, in Glegg, S., Hardy, G. and Nord, W. (Eds), Handbook of Organization Studies, Thousand Oaks, CA, pp. 175-190.

Vilaseca, A. (2002), "The shareholder role in the family business: conflict of interests and objectives between nonemployed shareholders and top management team", Family Business Review, Vol. 15 No. 4, pp. 299-320.

Villalonga, B. and Amit, R. (2006), "How do family ownership, control and management affect firm value?”, Journal of Financial Economics, Vol. 802, p. 385.

Ward, J. (1987), Keeping the Family Business Healthy. How to Plan for Continuous Growth, Profitability and Family Leadership, Jossey Bass, San Francisco, CA.

Ward, J. (1991), Creating Effective Boards for Private Enterprises, Jossey-Bass, San Francisco, CA.

Ward, J.L. and Handy, J.L. (1988), “A survey of board practices”, Family Business Review, Vol. 1 No. 3, pp. 289-308.

Zahra, S.A. and Pearce, J.A. III (1989), "Boards of directors and corporate financial performance: a review and integrative model", Journal of Management Vol. 15, pp. 291-334.

Zahra, S.A. and Sharma, P. (2004), "Family business research: a strategic reflection", Family Business Review, Vol. 174, pp. 331-346.

Zajac, E.J. and Westphal, J.D. (2004), "The social construction of market value: institutionalization and learning perspectives on stock market reactions", American Sociological Review, Vol. 69 No. 3, pp. $433-457$.

Zucker, L.G. (1987), "Institutional theories of organization”, Annual Review of Sociology, Vol. 13 No. 1, pp. $443-464$.

\section{Further reading}

Carney, M. and Gedajlovic, E. (2003), "Governance, inducements-contributions and organizational capabilities", paper presented at the, Academy of Management Conference, Seattle, WA.

DiMaggio, P.J. and Powell, W.W. (1991), "The iron cage revisited: institutional isomorphism and collective rationality in organizational fields, 63-82", in Powell, W.W. and DiMaggio, P.J. (Eds), The New Institutionalism in Organization Analysis, University of Chicago Press, Chicago.

\section{Corresponding author}

Maria Jose Parada can be contacted at: mariajose.parada@esade.edu

For instructions on how to order reprints of this article, please visit our website:

www.emeraldgrouppublishing.com/licensing/reprints.htm

Or contact us for further details: permissions@emeraldinsight.com 